\title{
METHODOLOGICAL PRINCIPLES FOR IMPROVING THE PROFESSIONAL TRAINING OF DOCTORS IN THE PROCESS OF STUDYING BIOLOGICAL AND BIOORGANIC CHEMISTRY IN THE ASPECT OF CHEMICAL SAFETY
}

\author{
Alla Ishchenko, Lyudmyla Hayova, Oksana Horkunenko
}

\begin{abstract}
Chemical safety is a component of general and professional competencies of future doctors, namely: general culture (handling of chemical substances, household chemicals); promotion of a healthy lifestyle; prevention of diseases of the population; protection and preservation of public health; providing emergency medical care in emergencies (related to chemical accidents). The article substantiates the method of improving the professional training of future doctors by integrating modern aspects of chemical safety into biochemical training. The potential of the discipline "Biological and Bioorganic Chemistry" as a tool for the formation of competence in chemical safety of future physicians, due to a combination of theoretical training (training material on the mechanisms of inhibition of enzymatic reactions by toxicants; inhibitors and disintegrants of oxidative phosphorylation; molecular mechanisms of action of toxicants; formation and disposal of endogenous toxins; biotransformation of xenobiotics) and laboratory workshops (handling of chemical reagents; modern approaches to hazard labeling and labeling of chemicals; toxicants' action modeling) is substantiated. The method of studying the educational material of the discipline "Biological and Bioorganic Chemistry" in the context of modern ideas on chemical safety is described. It provides a comprehensive application of modern teaching methods (design, solving situational problems, laboratory experiments, simulating the action of hazardous chemicals, testing) and teaching aids (glossary of terms on biochemical aspects of chemical safety; video lectures and methodical recommendations for independent work of students). The stages of the study method realization of the "Biological and bioorganic chemistry" discipline's educational material in the context of modern ideas on chemical safety are described. These are the substances' handling culture formation; formation of biochemical aspects of chemical safety; integration of modern ideas in the field of chemical safety and biochemical components
\end{abstract}

Keywords: professional training of doctors, biological and bioorganic chemistry, chemical safety

How to cite:

Ishchenko, A., Hayova, L., Horkunenko, O. (2021). Methodological principles for improving the professional training of doctors in the process of studying biological and bioorganic chemistry in the aspect of chemical safety. ScienceRise: Pedagogical Education, 5 (44), 34-40. doi: http://doi.org/10.15587/2519-4984.2021.241453

(C) The Author(s) 2021

This is an open access article under the Creative Commons CC BY license hydrate

\section{Introduction}

Professional training of doctors in the context of today's challenges is one of the key principles of state policy in the field of higher education. In the light of updating and accreditation of educational program 222 "Medicine" of the educational level "Master" there is an introduction of the international standards of preparation, modernization of working programs concerning approaches to studying of basic disciplines, including biological chemistry.

\section{Literary review}

In the educational and methodical literature the modern tendencies of introduction of the competence approach in higher medical education are investigated. Approaches to the content and list of general and professional (professional) competencies of the future medical worker are substantiated [1-4].

General and professional competencies of the future doctor in terms of chemical safety are prescribed in the industry standard of higher education field of knowledge 22 "Health", specialty 222 "Medicine": the desire to preserve the environment; ability to carry out sanitary and hygienic and preventive measures; ability to conduct epidemiological and medical-statistical studies of public health; ability to assess the impact of the environment on the population health (individual, family, population); ability to take measures to improve resource efficiency [3].

The experience of reforming higher medical education is revealed, which involves updating the content of curricula [5, 6], combining theoretical and clinical training of future doctors [7], integrated study of educational material [8], group work of students, application of problem-based learning [9], cloud learning services [10], modules of independent learning in the online mode [11] of the complex exam in basic sciences [12]. The structure of professional competence of the future doctor in the context of formation of diagnostic, clinical and prophylactic components is substantiated [13]. 
The pedagogical conditions of formation of professional competencies of future doctors during naturalscientific preparation, providing development of the professional environment, actualization of the professional potential of natural-scientific preparation, orientation of educational-cognitive and scientific activity of students are considered [13, 14].

Peculiarities of introduction of the integrated system of natural-scientific and professional-practical training of physicians as an integral part of the formation of integral, general and professional competencies are revealed $[13,14]$.

The application of interactive methodological techniques for the acquisition of general and professional competencies in the study of bioorganic and biological chemistry in higher medical education is studied $[2,15]$.

The issues of studying the course "Biological and Bioorganic Chemistry" by students of medical and psychological faculty [16], passing the licensed integrated exam "Step 1. General medical training" [17], the formation of general competencies in the teaching of biochemistry are considered [13].

Peculiarities of formation of practical skills of students of medical faculties in the course of biological and bioorganic chemistry are analyzed [13]. However, the question of future doctors' mastering modern approaches to hazard labeling, handling of chemicals, responding to chemical hazards remains open. The normative academic discipline "Biological and Bioorganic Chemistry" allows to integrate modern aspects in the field of chemical safety with the study of biochemical mechanisms of exposure to toxicants $[18,19]$.

\section{The aim and objectives of the study}

The aim of the work is to substantiate the studying methodology of the educational material of the discipline "Biological and Bioorganic Chemistry" in the context of ideas on chemical safety. To achieve this goal, the following tasks are defined:

1. To substantiate educational-methodical and educational-technological conditions of realization of the studying methodology of the educational material of the discipline "Biological and bioorganic chemistry" in the context of modern ideas on chemical safety;

2. To develop and characterize the stages of implementation of the methodology of studying educational material of the discipline "Biological and Bioorganic Chemistry" in the context of modern ideas on chemical safety.

\section{Materials and methods}

Theoretical research methods were used to fulfill the set tasks and goals. Analysis, synthesis, comparison, generalization for research and analysis of the scientific literature on the training of future physicians in the context of the competence approach, modern ideas on chemical safety, biochemical training. Analysis, synthesis, comparison, generalization, classification, systematization to substantiate the educationalmethodological and educational-technological conditions of the methodology of studying the educational material of the discipline "Biological and Bioorganic Chemistry" in the context of modern ideas on chemical safety. Modeling for the development and characterization of the stages of implementation of the method of studying the educational material of the discipline "Biological and Bioorganic Chemistry" in the context of modern ideas on chemical safety.

The described author's method of studying the education material of the discipline "Biological and bioorganic chemistry" in the context of modern ideas on chemical safety was tested. On the basis of the National Medical University named after O.O. Bogomolets, the formative stage of the pedagogical experiment was carried out with the involvement of 299 first and second year students of medical faculties No. 1-4 and eight teachers. Students were divided into two groups: experimental (EG) - 146 and control (CG) - 153 people. Informational consent was obtained from all participants.

According to the extended questionnaire, students of CG and EG had homogeneous values of the initial level of formation of motivational-value, cognitive and activity criteria of competence in chemical safety (Pearson's consistency criterion $\left(\chi^{2}\right)$ was applied).

\section{Research results and their discussion}

The method of studying the educational material of the discipline "Biological and bioorganic chemistry" in the context of modern ideas on chemical safety involves the integrated application of educationalmethodological educational-technological conditions:

- use of teaching methods (design, solution of situational problems, performance of laboratory experiments, simulating the action of hazardous chemicals, testing), teaching aids (glossary of terms on biochemical aspects of chemical safety);

- video lectures and methodical recommendations for independent work of students), individual and group activity of students.

During the study of the normative discipline, the pedagogical technology was introduced in three stages (Fig. 1): formation of handling culture of chemicals; formation of knowledge on biochemical aspects of chemical safety; integration of modern ideas in the field of chemical safety and biochemical components. 


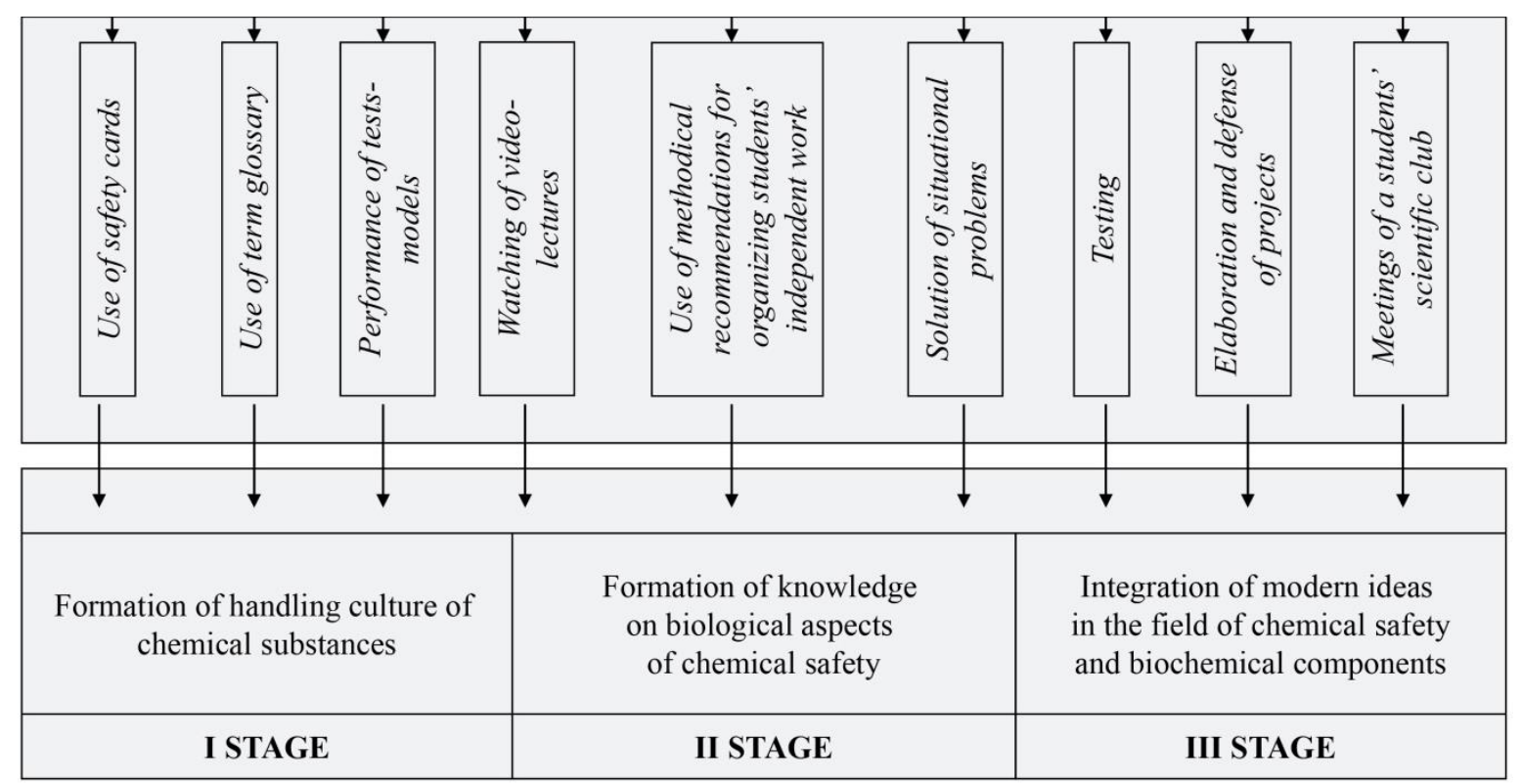

Fig. 1. The study of biological and bioorganic chemistry in the context of modern ideas on chemical safety

The first stage of implementation of methods for studying biological and bioorganic chemistry in the context of modern ideas on chemical safety involves updating knowledge about the rules of work in a chemical laboratory. For this purpose, a set of educational materials was used: safety cards for work and handling of chemicals (representatives of the main classes of inorganic and organic compounds), a glossary of terms, a video lecture "Modern approaches to hazard classification and labeling of chemicals."
The use of safety cards should be carried out at the first lesson on "Biological and Bioorganic Chemistry" as an element of safety training while working in a biochemical laboratory. The structure of the safety card presents information about the name of the compound, its structural formula, elements of labeling in the form of icons, signal words, brief hazard characteristics, hazard prevention measures, regulatory and information signs, illustrating safety rules when working with chemicals (Fig. 2).

\begin{tabular}{|c|c|c|c|}
\hline $\begin{array}{l}\text { Ethanoic acid } \\
\mathrm{CH}_{3} \mathrm{COOH}\end{array}$ & $\begin{array}{l}\text { Cautious! } \\
\text { Brief description of the hazard } \\
\text { H-phrases: 226-314; flammable liquids and } \\
\text { their vapors; cause severe skin burns and eye } \\
\text { damage. } \\
\text { Measures to prevent the hazard P-phrases: } \\
280-301+330+331-307+310-305+351+ \\
338 \text { use protective gloves / protective clothing / } \\
\text { eye / face protection; in case of swallowing: } \\
\text { rinse mouth, do not induce vomiting; in case of } \\
\text { negative impact - immediately contact the } \\
\text { information center or call a doctor; in case of } \\
\text { contact with eyes - rinse thoroughly with water } \\
\text { for several minutes; if possible - remove } \\
\text { contact lenses; continue rinsing the eyes }\end{array}$ & $\begin{array}{l}\text { Cautious! } \\
\text { Acid substance } \\
\text { Flammatious! } \\
\text { substances } \\
\text { In case of } \\
\text { getting the } \\
\text { reagent on skin } \\
\text { or clothing - } \\
\text { rinse with } \\
\text { water and } \\
\text { neutralize }\end{array}$ & $\begin{array}{l}\text { Use protective } \\
\text { gloves }\end{array}$ \\
\hline
\end{tabular}

Fig. 2. Safety card for ethanoic acid 
During practical classes, future physicians have the opportunity to get acquainted with the handouts (safety cards) and express judgments about the type of hazards, caused by a particular reagent; a list of safety precautions to be followed when working with specific chemicals; propose algorithms of actions that must be followed when working with hazardous chemical reagents.

These safety cards should be used in conjunction with the glossary of basic terms, relating to labeling, hazard types, rules of operation and handling of chemical products [20]. The glossary provides an interpretation of the following basic concepts: explosive chemical products, designating signs, prohibition signs, hazard prevention measures, danger signs or icons, information signs, carcinogen, corrosive chemical products, brief hazard characteristics, flammable chemical products, labeling, mutagen, safety data sheet of chemical products, pyrophoric chemical products, warning labeling of chemical products, warning signs, regulatory signs, self-reactive chemical products, sensitization, signal word, toxic chemical products, chemical products that have a sensitizing effect. The work of future doctors with the glossary is not limited to the first lesson, students seek the interpretation of incomprehensible concepts throughout the study of bioorganic and biological chemistry.

To organize independent work of students, a video lecture "Biochemical aspects of chemical safety. Part I: Modern approaches to the classification and labeling of chemicals" was created and posted on the YouTube channel NMU TV. The use of video lectures allows students to summarize the information read, highlight the main content load, if necessary, listen to and analyze the material several times.

The lecture reveals the basic component of modern ideas on chemical safety - current international and national standards for hazard designation and labeling of chemical products: The globally agreed system of classification and labeling of chemicals - a tool for establishing uniform rules for hazard labeling; DSTU GOST 31340: 2009 "Warning labeling of chemical products. General requirements "(field of application; types of hazards - classification of physical hazards, hazards to human health and the environment; labeling elements icon; signal word; H-phrases or brief hazard characteristic (Hazard statements); P-phrases or hazard prevention measures (Precautionary statements); Standard NFPA 704 of the National Fire Protection Association (concept of square hazards, designation of hazards to human health, fire hazards, hazards of chemical interaction, special notes); DSTU GOST 30333-2009 "Safety data sheet of chemical products. General requirements "(structure of the safety data sheet; use of information on chemicals, described in the MSDS in further professional activities hazard identification; first aid measures; measures and means of fire safety; measures to prevent and eliminate emergencies and their consequences; rules for the storage and handling of substances, hazardous exposure controls and personal protective equipment, physical and chemical properties, stability and reactivity, toxicity information, environmental information, waste disposal recommendations, transportation information), online system on hazardous chemicals - GESTIS in the context of searching for verified information on chemicals labeling, hazard characteristics, hazard prevention measures, toxicological characteristics of chemicals.

At the second stage of implementation of methods of studying biological and bioorganic chemistry in the context of modern ideas on chemical safety (formation of biochemical aspects of chemical safety) it is expedient to use safety cards, model experiments, situational tasks, video lectures, methodical recommendations for students and teachers, test tasks.

The use of safety cards should be carried out at practical classes during the study of the entire course of bioorganic and biological chemistry. The structure of the safety card (Fig. 3) was expanded, in addition to the standard content blocks, which students learned at the first lesson (compound name, structural formula, registration number, icons, signal word, information on the type of danger, advisory information, safety measures), the section on toxicological characteristics (LD50, acute toxicity, chronic toxicity) was given.

Safety cards for bioorganic compounds were developed, the structure and properties of which were considered in the theoretical part of the lesson (intermediates of metabolic processes: pyruvate, lactate, oxaloacetate, acetone, $\beta$-hydroxybutyric acid; endogenous toxins, formed in the human body: skatole, indole, phenol, cresol; drugs: salicylic acid, acetylsalicylic acid, salol), toxicants (studied in the context of inhibition of enzymatic reactions, the formation of pathological forms of hemoglobin, mutagenic factors, etc.).

Future physicians at practical classes, working with safety cards, substantiate the rules of work with chemicals, safety measures and based on the analysis of handouts, make judgments about the toxicity of compounds. When studying topics, related to biochemical aspects of chemical safety (mechanisms of inhibition of enzymatic reactions by toxicants; actions of inhibitors and dissociators of oxidative phosphorylation; molecular mechanisms of action of toxicants; formation and disposal of endogenous toxins; biotransformation of xenobiotics), students compare physiological, compounds (intermediate, toxicant, xenobiotic), given in the safety cards and in the content of theoretical material of the relevant practical lesson. Thus, one of the results of the study of bioorganic and biological chemistry in future physicians will be the formation of an associative series "hazard designation - molecular mechanisms of action of the compound - safety measures when working with it."

The content of the laboratory workshop of the discipline "Biological and Bioorganic Chemistry" provides for students to perform laboratory experiments, demonstrating the toxic effects of xenobiotics, toxicants: the effect of phosphacol and calcium ions on cholinesterase activity, the study of oxidative phosphorylation in mitochondria and 2,4-dinitrophenol, detection of indican in urine (Obermeier test); determination of aniline-phydroxylase activity of liver microsomes.

Performing laboratory work, students experimentally confirm the theoretical material, draw conclusions about the clinical and diagnostic value of the results. Before performing the experiment, future physicians review the developed safety cards of the toxicant, in which special attention is paid to the relationship "labeling - the impact on human health", and during the practical work, this effect is modeled and studied. 


\begin{tabular}{|c|c|c|}
\hline $\begin{array}{c}\text { Ethanal } \\
\text { Ethanal } \\
\text { IUPAC } \\
\text { PubChem } 117 \\
C A S \text { T5-07-0 }\end{array}$ & $\begin{array}{l}\mathrm{LD}_{50} 661 \mathrm{mg} / \mathrm{kg} \text { (rats). } \\
\text { Acute toxicity: irritation } \\
\text { of the mucous } \\
\text { membranes of the eyes, } \\
\text { nose, throat, headache, } \\
\text { redness and swelling of } \\
\text { the lungs. Chronic } \\
\text { toxicity: bronchitis, } \\
\text { damage to the walls of } \\
\text { blood vessels and } \\
\text { connective tissue, } \\
\text { changes in the liver, } \\
\text { diarrhea, signs of renal } \\
\text { dysfunction, mental and } \\
\text { nervous disorders that } \\
\text { resemble chronic alcohol } \\
\text { abuse }\end{array}$ & $\begin{array}{l}\text { Risk phrases: } \\
\text { H phrases - information about the type } \\
\text { of hazard. } \\
\text { H phrases: 224-351-319-335 extremely } \\
\text { flammable liquids and vapors; } \\
\text { likely to cause cancer; cause } \\
\text { significant eye irritation; may cause } \\
\text { respiratory irritation. } \\
P \text { phrases - information of advisory } \\
\text { nature } \\
\text { P phrases: } 210-223-281-305+351+ \\
338-308+313 \\
\text { protect from heat / sparks / open fire / } \\
\text { hot surfaces, do not smoke; prevent } \\
\text { contact with water, as possible violent } \\
\text { reaction and outbreaks; use personal } \\
\text { protective equipment; in case of } \\
\text { contact with eyes: carefully rinse eyes } \\
\text { with water for several minutes; in case } \\
\text { of negative action or feeling unwell: } \\
\text { consult a doctor / ambulance. }\end{array}$ \\
\hline
\end{tabular}

Fig. 3. Safety card for ethanal compound

Solving situational problems is an obligatory element of practical training in bioorganic and biological chemistry in institutions of higher medical education. Methods of studying biological and bioorganic chemistry in the context of modern ideas on chemical safety involves the use of situational tasks on the molecular mechanisms of action of toxicants, the formation and neutralization of endogenous toxins, biotransformation of xenobiotics.

Here is an example of such a problem. A 40-yearold man, working in an industrial enterprise, the production process of which involves the use of equipment, containing mercury, was hospitalized. As a result of violation of safety rules regarding the operation of the devices, the working area was contaminated with mercury vapor. The disease developed gradually: there was increased fatigue, drowsiness, general weakness, headache, dizziness, apathy, trembling of the fingertips with excitement - "mercury tremor", cardiac arrhythmia, low blood pressure. It is necessary to substantiate the molecular mechanisms of the toxicant and the possibility of therapeutic use of complexones.

The solution of the above situational problem is offered to future physicians while studying the topic "Study of the regulation of enzymatic processes. Enzymopathy. Enzyme diagnostics". Accordingly, in order to correctly answer the task, students must describe and provide a scheme of action of noncompetitive inhibitors, the mechanism of their reactivation. We offer the use of this format of situational problems throughout the study of the entire course of bioorganic and biological chemistry.
To organize independent work of students while studying the topic "Research of biotransformation of xenobiotics and endogenous toxins. Microsomal oxidation, cytochrome R-450", a video lecture "Biochemical aspects of chemical safety. Part II: Biotransformation of Xenobiotics and Endogenous Toxins", was created and posted on the YouTube channel NMU TV

The lecture covers issues, related to biochemical aspects of chemical safety: biochemical functions of the liver, detoxification function of the liver, the concept of xenobiotics and endogenous toxins that are biotransformed and neutralized in the liver, characteristics of the stages of biotransformation of xenobiotics and endogenous toxins; reactions of the first stage of biotransformation of xenobiotics and endogenous toxins: oxidation, hydrolysis, reduction; work of the enzymatic system of cytochrome P450, reactions of the second stage of biotransformation of xenobiotics and endogenous toxins: methylation, acetylation, conjugation with 3'phosphoadenosine-5'-phosphosulfate, glucuronic acid, Sadenosylmethionine, glutathione.

In addition to the video lecture on "Study of the processes of biotransformation of xenobiotics and endogenous toxins. Microsomal oxidation, cytochrome R-450", methodical guidelines for teachers and ones for the organization of independent work of students were developed.

The process of studying the discipline "Biological and Bioorganic Chemistry" provides for the current, final control of self-control of knowledge in the form of testing, as the subject is included in the list of disciplines TII "Step-1. GTT». To test the knowledge of chemical safety 
in future doctors, booklets, test tasks TII "Step 1" for 2005-2019 were analyzed. Test tasks, related to some aspects of chemical safety during the study of the discipline "Biological and Bioorganic Chemistry": toxicity, transport forms, ammonia disposal; oxidative phosphorylation inhibitors in mitochondria and electronic transport; influence of xenobiotics (3,4-benzopyrene, carbon monoxide, nitrates, arsenates, bismuth preparations) and their biotransformation, were selected. In practical classes we offer to analyze the content of the conditions and answers to such test tasks.

At the third stage of the methodology of studying biological and bioorganic chemistry in the context of modern ideas on chemical safety in order to integrate the components of chemical safety, we recommend using the project method [18], organizing meetings of student research groups, conducting training seminars to discuss the issues of hazard designation and labeling of chemicals, features of biotransformation of persistent organic pollutants, toxicants, carcinogens, etc.

After the completion of the purposeful pedagogical influence, the diagnostics of the levels of formation of motivational-value, cognitive and activity criteria of competence in chemical safety of future doctors was carried out in accordance with the developed indicators.

The positive dynamics in the formation of motivational and value (high - $37.67 \%$ in EG and $7.19 \%$ in CG; sufficient $-46.58 \%$ in EG and $34.64 \%$ in CG; middle $-10.27 \%$ in EG and $41.18 \%$ in CG; low $-5,48 \%$ in EG and $16.99 \%$ in CG, $\chi^{2} 70.14$, limit value 11.34 , the difference is statistically significant at $p<0.01)$. Cognitive (high $-32.19 \%$ in EG and $10.46 \%$ in CG, sufficient $52,06 \%$ in EG and $27.45 \%$ in CG, middle $-11.64 \%$ in EG and $49.67 \%$ in CG, low $-4.11 \%$ in EG and $12.42 \%$ in CG, $\chi^{2} 69.11$, limit value 11.34, the difference is statistically significant at $\mathrm{p}<0.01$ ) and activity (high $-23.97 \%$ in EG and $7.19 \%$ in CG, sufficient $-50.69 \%$ in EG and $16.99 \%$ in CG, middle $-21.23 \%$ in EG and $54.25 \%$ in CG, low $-4.11 \%$ in EG and $21.57 \%$ in CG; $\chi^{2} 77.85$, limit value 11.34 , the difference is statistically significant at $\mathrm{p}<0.01)$ CSC criteria in the process of teaching bioorganic and biological chemistry in students of the experimental group was established.

The author's method of studying biological chemistry in the context of modern ideas on chemical safety allows future doctors to more consciously study ecological and hygienic disciplines. It is necessary to deepen and develop knowledge, understanding, cognitive and practical skills in the field of chemical safety, formed with the help of the course "Biological and Bioorganic Chemistry", in the basic disciplines "Hygiene and Ecology", "Emergency Medicine", "Occupational Health", "Social Medicine", "Health Care Organization". When studying these disciplines, future doctors study the basics of prevention: the impact of environmental factors on the health of various groups; methods of hygienic assessment of the impact of environmental factors on public health; laws of hygienic science and general laws of connection of health with factors and conditions of the environment of human life; diseases of non-infectious origin; princi- ples of a healthy lifestyle and the basics of personal hygiene.

In further research, it is desirable to take into account data on safety of drugs, the use of chemical reagents in laboratory practice, qualification risks and potential hazards in accordance with international ISO standards, implementation of the guidelines of the International System of Safety and Health in the industry (OHSAS), algorithms for the prevention of occupational injuries while working in a chemical laboratory.

We see prospects for further research in the modification of educational content and its experimental verification in terms of distance learning.

\section{Conclusions}

1. The normative academic discipline "Biological and Bioorganic Chemistry" has significant potential in the formation of competence in chemical safety of future physicians. Since during the study of the educational material on biochemical aspects of chemical safety (mechanisms of inhibition of enzymatic reactions by toxicants, the action of inhibitors and disintegrants of oxidative phosphorylation, molecular mechanisms of action of toxicants, formation and disposal of endogenous toxins, mechanisms of biotransformation of xenobiotics), the formation of an associative series "hazard designation molecular mechanisms of action (influence) of the compound (toxicant) - safety measures when working with it" takes place. The educational-methodical and educational-technological conditions of realization of the methodology of studying of the educational material of the discipline "Biological and bioorganic chemistry" in the context of modern ideas on chemical safety were presented, providing application of modern methods of training (designing, solution of situational problems, performance of laboratory experiments, simulating the action of hazardous chemicals, testing), teaching aids (glossary of biochemical aspects of chemical safety; video lectures and guidelines for independent work of students), individual and group activities of students.

2. The stages of realization of the studying methodology of the educational material of the discipline "Biological and bioorganic chemistry" in the context of modern ideas on chemical safety were developed and characterized: formation of culture of handling of chemical substances; formation of biochemical aspects of chemical safety; integration of modern ideas in the field of chemical safety and biochemical components. The expediency of using safety cards of bioorganic compounds (intermediates of metabolic processes; endogenous toxins, drugs) to solve problems, filled with professionally relevant information in the field of chemical safety (situational tasks, test tasks, performance of projects and laboratory experiments that simulate the action of hazardous compounds) was substantiated.

The described method of studying biological and bioorganic chemistry in the context of modern ideas on chemical safety is introduced into the educational process of the National Medical University named after O. O. Bogomolets. 


\section{References}

1. Ishchenko, A. (2021). Chemical safety as a component of general and professional competences in training of future doctors. ScienceRise: Pedagogical Education, 2 (41), 31-36. doi: http://doi.org/10.15587/2519-4984.2021.228123

2. Gerush, I. V., Grygorieva, N. P., Davydova, N. V. (2017). Modern approaches to teaching bioorganic and biological chemistry in medical universities. Medical and Clinical Chemistry, 18 (4) 114-117. doi: http://doi.org/10.11603/mcch.2410-681x.2016.v0.i4.7290

3. Haluzevyi standart vyshchoi osvity pidhotovky na druhomu (mahisterskomu) rivni Mahistra u haluzi znan 22 - «Okhorona zdorovia» za spetsialnistiu 222 «Medytsyna» (2018). Kyiv-Vinnytsia. Available at: https://www.vnmu.edu.ua/downloads/pdf/standart_ VO_med_20190408-140905.pdf

4. The Tuning Project (Medicine). Available at: http://www.unideusto.org/tuningeu/images/stories/Summary_of_outcomes_TN/ Learning_Outcomes_Competences_for_Undergraduate_Medical_Education_in_Europe.pdf

5. Reibnegger, G., Haas, J., Neges, H., Smolle, J. (2008). Die Reform des Medizinstudiums an der Medizinischen Fakultät/Universität Graz. Zeitschrift Für Hochschulentwicklung, 3 (3), 48-61. doi: http://doi.org/10.3217/zfhe-3-03/05

6. Burger, W., Dudenhausen, J. W., Kiessling, C., Scheffner, Wilke, D., Reform des Medizinstudiums, A. (2003). Positive Erfahrungen an der Charité Berlin/W. Burger at. Deutsches Ärzteblatt, 100 (11), 686-689.

7. Hamouda, O., Sweilam, M., Abdellah, A., Aboonq, M. S., Abdel-Halim, O. B., El Sayed, S. M., Hamouda, A. O. (2019). Outcome and Future Perspectives of Pioneering Integrative Medicine Education in Taibah University: Ten Years' Experience in Saudi Arabia Medical Schools (A Medical Education Article). American Journal of Educational Research, 7 (1), 69-75. doi: http://doi.org/10.12691/education-7-1-11

8. Voskoboinikova, G., Doroshenko, T., Rudyk, A. (2019). Integrated approach to providing technology of educational processes in the master's conditions in institutions of higher education. Modern Science-Moderní věda. Praha. České Republika, Nemoros, 3, 95-103.

9. Nizhenkovska, I., Reva, T., Chkhalo, O., Holovchenko, O. (2020). Technology-Driven Self-Directed Learning of Graduate Pharmaceutists: Adding Value through Entrepreneurship. International Journal of Learning, Teaching and Educational Research, 19 (6), 111-126. doi: http://doi.org/10.26803/ijlter.19.6.7

10. Stuchynska, N. V., Belous, I. V., Mykytenko, P. V. (2021). Use of modern cloud services in radiological diagnostics training. Wiadomości Lekarskie, 74 (3), 589-595. doi: http://doi.org/10.36740/wlek202103205

11. Maloney, S., Tai, J., Paynter, S., Lo, K., Ilic, D. (2013). Self-Directed Online Learning Modules: Students' Behaviours and Experiences. Pharmacy, 1 (1), 8-15. doi: http://doi.org/10.3390/pharmacy1010008

12. Johnson, T. R., Khalil, M. K., Peppler, R. D., Davey, D. D., Kibble, J. D. (2014). Use of the NBME Comprehensive Basic Science Examination as a progress test in the preclerkship curriculum of a new medical school. Advances in Physiology Education, 38 (4), 315-320. doi: http://doi.org/10.1152/advan.00047.2014

13. Tokaryk, H. V. (2016). Formuvannia praktychnykh navychok u studentiv II-ho kursu medychnoho fakultetu pry vykladanni biokhimii. Visnyk problem biolohii i medytsyny, 4 (134), 156-158.

14. Paikush, M. A. (2018). The formation of professional competencies of the futuredoctor by integration of natural science and the professional-practical disciplines. Molod i rynok, 6 (161), 98-102.

15. Kniazieva, M. V. (2014). Otsinka rezultativ vvedennia Bolonskoho protsesu v systemu vyshchoi osvity (za materialamy FEBS Congress 2013). The Ukrainian Biochemical Journal, 86 (5), 282-238.

16. Nizhenkovska, I. V., Yanitska, L. V., Stechenko, O. V., Vlasenko, M. S., Pradiy, T. P. (2012). The features of biological chemistry teaching inmedical-psychological faculty of O. O. Bohomolets National Medical University. Медична освіта, 3, 66-68.

17. Gayova, L., Yanitskaya, L., Obernikhina, N., Sanzhur, T. (2017). Licensed integrated examination "Step 1. Dentology" in the Bogomolets National Medical University as education quality control indicator: inter-dissiplanal integration. Monitoring aspect. ScienceRise: Pedagogical Education, 7 (15), 15-18. doi: http://doi.org/10.15587/2519-4984.2017.107335

18. Ishchenko, A. (2018). The formation of knowledge on toxicants as the components of chemical safety for future doctors during their studies of bioorganic chemistry and biochemistry. ScienceRise: Pedagogical Education, 5 (25), 47-52. doi: http://doi.org/10.15587/2519-4984.2018.139414

19. Ishchenko, A. A. (2018). Building competence on chemical safety for future doctors during their studies of Bioorganic Chemistry and Biochemistry: results of ascertaining experiment. Science and Education a New Dimension, VI (174) (72), $14-17$. doi: http://doi.org/10.31174/send-pp2018-174vi72-03

20. Ishchenko, A. A., Tolmachova, V. S., Dubovyk, O. A., Fitsailo, S. S. (2015). Markovannia khimichnykh rechovyn ta khimichnoi produktsii. Znaky bezpeky. Ternopil: Mandrivets, 28.

Received date 17.08.2021

Accepted date 21.09.2021

Published date 30.09.2021

Alla Ishchenko*, PhD, Associate Professor, Department of Medical Biochemistry and Molecular Biology, Bogomolets National Medical University, T. Shevchenko blvd, 13, Kyiv, 01601

Liudmyla Haiova, Doctor of Medical Sciences, Professor, Head of Department, Department of Medical biochemistry and molecular biology, Bogomolets National Medical University, T. Shevchenko blvd, 13, Kyiv, 01601

Oksana Horkunenko, PhD, Department of Medical Biochemistry and Molecular Biology, Bogomolets National Medical University, T. Shevchenko blvd, 13, Kyiv, 01601

E-mail: aylostra22@gmail.com

*Corresponding author: Alla Ishchenko,e-mail: ischenko.alla.a@gmail.com 